\title{
Induksi Teknologi pada Industri Kreatif Kampung Sentra Blangkon : Promosi, Pengelolaan Pemesanan dan Penjualan
}

\author{
Eko Purwanto $^{1}$, Bangun Pradjadi Cipto Utomo ${ }^{2}$, Pipin Widyaningsih ${ }^{3}$ \\ 1,2,3 Universitas Duta Bangsa Surakarta; J1. Bhayangkara 55 Surakarta,0271719552 \\ ${ }^{1}$ Fakultas Ilmu Komputer Program Studi Teknik Informatika, Universitas Duta Bangsa \\ ${ }^{2,3}$ Fakultas Ilmu Komputer Program Studi Teknik Informatika, Universitas Duta Bangsa \\ e-mail : ${ }^{1}$ eko_purwanto@udb.ac.id, ${ }^{2}$ bangun_prajadi@udb.ac.id, ${ }^{3}$ pipin_widya@udb.ac.id
}

\begin{abstract}
Abstrak
Kampung Sentra Blangkon Petrojayan Serengan merupakan daerah industri kreatif yang memproduksi blangkon dan menjualnya. Metode promosi dan penjualan blangkon di kampong blangkon petrojayan dilakukan melalui pameran, informasi mulut ke mulut dan beberapa pedagang telah memanfaatkan teknologi promosi dan pemasaran melalui Short Message Service (SMS) dan intenet. Pengenalan produk blangkon pada media internet seperti facebook atau media social lainnya hanya menampilkan gambar tanpa spesifikasi produk maupun cara memesan dan membelinya. Hal ini tentunya menyulitkan konsumen untuk mengetahui detail produk blangkon dan melakukan transaksi pembelian barang. Kegiatan PKM ini adalah melakukan induksi teknologi yang terdiri dari aplikasi promosi dan aplikasi manajemen peneglolaan pemesanan dan penjualan secara online. Paket aplikasi yang akan diterapkan pada mitra adalah aplikasi Elektronik Market Place dan Manajemen Penjualan. Kegiatan ini memiliki target untuk perluasan tempat pemasaran secara elektronik (e-market place) dan perbaikan manajemen pengelolaan pemesanan dan penjualan secara online. Kegiatan Induksi teknologi dilakukan dalam lima tahap yaitu (1) Penyusunan Materi, (2) Pelatihan, (3) Persiapan peralatan, Konfigurasi Sistem dan Implementasi Sistem, (4) Pendampingan dan (5) Monitoring. Pendekatan yang dilakukan untuk proses penyusunan materi dan pelatihan adalah pendekatan konsep-proses. Pendekatan yang digunakan untuk proses pendampingan adalah pendekatan Project Based. Pendekatan yang digunakan untuk kegiatan monitoring adalah problem solving.
\end{abstract}

Kata kunci : Induksi, Teknologi, Promosi, Manajemen, Penjualan

\section{PENDAHULUAN}

Saat ini hampir dari seluruh masyarakat di kota besar sudah tidak asing jika mendengar internet, apalagi dengan jejaring sosial seperti facebook, twitter dan lain-lain [1]. Tidak jarang dari mereka pun pasti sudah pernah mengakses internet, atau bahkan hanya sekedar browsing Industri kreatif membutuhkan sumber daya kreativitas manusia yang cukup banyak khususnya dalam pembuatan desain dalam produknya [2]. Pemerintah Indonesia telah menetapkan 14 subsektor industri kreatif yaitu periklanan, arsitektur, pasar seni dan barang antik, kerajinan, desain, fashion, video, film dan fotografi, permainan interaktif, musik, seni pertunjukan, penerbitan dan percetakan [3]. Pengembangan industri kreatif diibaratkan menyerupai bangunan yang memiliki tiga komponen utama yaitu (1) pondasi adalah manusia yang merupakan aset utama, (2) lima pilar terdiri dari industri, teknologi, sumber daya, institusi dan Financial intermediary dan (3) bangunan atap meliputi 
intelektual, bisnis dan pemerintah [4].

Electronic market place adalah suatu bentuk pasar elektronik (virtual market) dimana pembeli dan penjual bertemu dan dihubungkan melalui suatu transaksi elektronik (online) yang dapat diakses secara cepat, aman dan dapat dilakukan dari mana saja dan kapan saja (terbebas dari jam kerja suatu tempat) [5].

Pembinaan manajemen usaha perlu dilakukan kepada usaha-usaha mikro karena minimnya pengetahuan yang mereka miliki disebabkan oleh pengetahuan dan akses informasi yang sangat kurang, sehingga pemberian pengetahuan mengenai manajemen usaha agar terus dilakukan untuk menyentuh usaha-usaha mikro yang ada di Indonesia [6].

Berdasarkan hal tersebut, dengan adanya pengawal pengembangan ekonomi kreatif yang lebih jelas, kalangan pelaku industri semestinya semakin bisa berharap banyak. Menurut pelaku UKM seni budaya (berdasarkan hasil wawancara dengan mitra pada tanggal 21 Februari 2018), masih banyak masalah yang dihadapi, antara lain adalah percepatan tumbuhnya teknologi informasi dan komunikasi, yang sangat erat kaitannya dengan perkembangan akses bagi masyarakat untuk mendapatkan informasi, bertukar pengetahuan dan pengalaman, sekaligus akses pasar. Kota Solo merupakan kota budaya yang memiliki beberapa pelaku usaha kerajinan dalam seni budaya dan hingga kini masih eksis berproduksi. Hal yang masih menjadi hambatan bagi UKM kerajinan seni budaya disini adalah kurangnya sarana promosi, sehingga mempersulit pengenalan produk kerajinan ke masyarakat. Sarana promosi yang digunakan saat ini hanya melalui media konvensional seperti brosur, pamflet dan lainnya.

Kampung Potrojayan, Serengan, Solo dikenal sebagai industri kreatif sentra pembuatan blangkon. Ada sekitar 25 rumah di kampung tersebut yang memproduksi blangkon di bawah Paguyuban "Paguyuban Maju Utomo". Keahlian membuat blangkon menurut warga didapatkan dari mbah joyo yang merupakan warga Baluwarti (Kawasan Keraton Kasunanan Surakarta) yang pindah ke Petrojayan pada Tahun 1970. Berbagai macam blangkon diproduksi di kampung tersebut, yang paling banyak dipesan ialah blangkon Solo dan Yogyakarta. Model blangkon yang dibuat antara lain model Solo dan Yogyakarta dan model Bali, Betawi, Madura, dan daerah lain, dibuat berdasarkan pesanan.
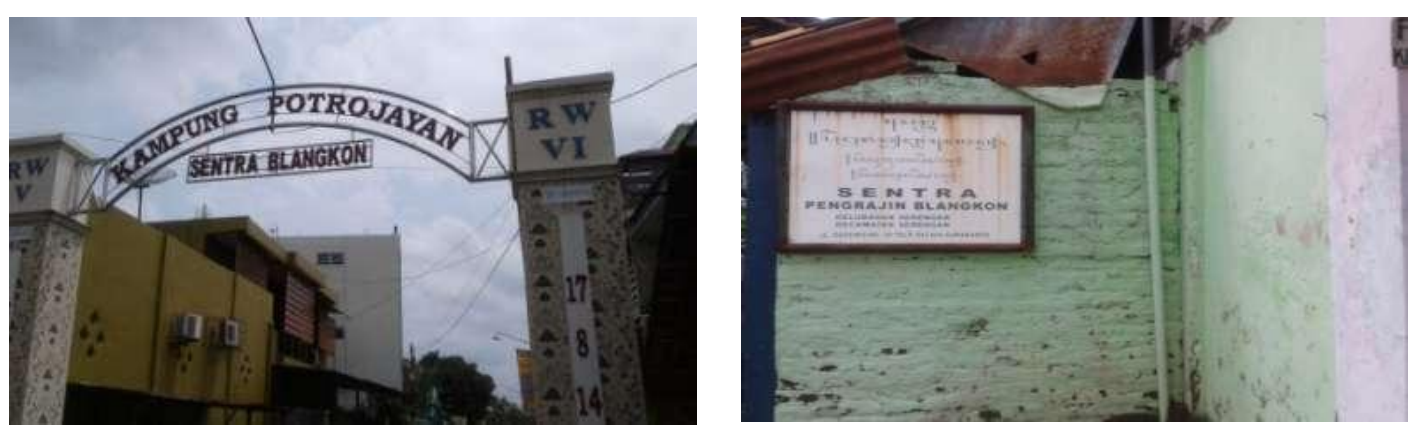

Gambar 1 Pintu Masuk Kawasan Industri Blangkon di kampung Potrojayan Solo 


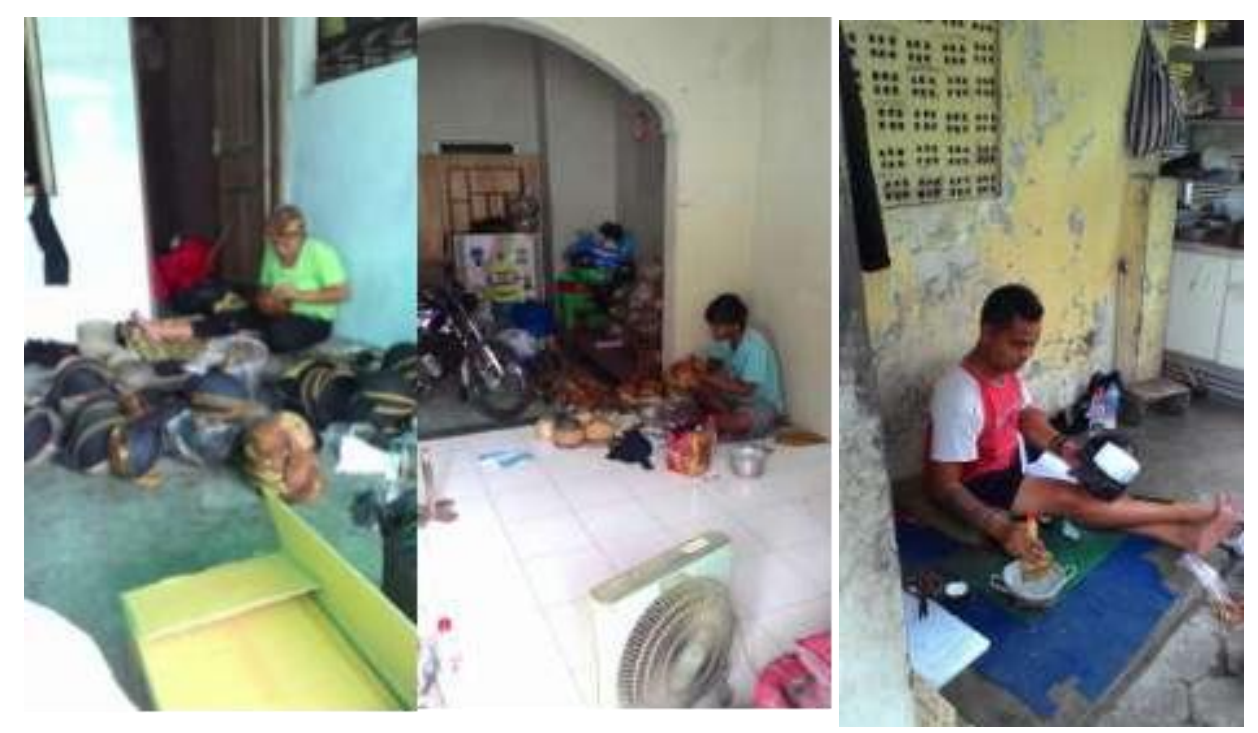

Gambar 2 Suasana produksi blangkon di kampung Potrojayan

Promosi atau pemasaran yang dilakukan saat ini oleh mitra pengusaha blangkon di bawah naungan paguyuban "Maju Utomo" yaitu berupa dipasarkan secara langsung ke pasar lokal maupun luar daerah yaitu ke pasar klewer, pasar keratin, yogyakarta dan semarang dikoordinir oleh ketua paguyuban. Selain itu pemasaran produk juga dilakukan melalui media komunikasi telepon seluler baik telepon langsung maupun dengan short message service (SMS). Pengenalan produk blangkon pada media internet seperti facebook atau media social lainnya hanya menampilkan gambar tanpa spesifikasi produk maupun cara memesan dan membelinya. Hal ini tentunya menyulitkan konsumen untuk mengetahui detail produk blangkon dan melakukan transaksi pembelian barang. Mitra belum mampu mengukur keberhasilan usaha penjualan produk karena tidak ada manajemen pengelolaan pemesanan dan penjualan produk dengan baik. Pengukuran keberhasilan penjualan produk hanya dapat dilihat dari banyak jumlah produksi, namun tidak dapat mengetahui berapa banyak pelanggan dan seberapa sering pelanggan melakukan transaksi pemesanan maupun penjualan.

Berdasarkan permasalahan tersebut, solusi yang ditawarkan untuk menangani permasalahan promosi dan manajemen pengelolaan pemesanan dan penjualan dengan menggunakan aplikasi E-Market Place dan Manajemen Penjualan Industri Blangkon. Teknologi ini terdiri dari dua paket, paket pertama adalah media promosi secara online dan pemasaran secara online yang menawarkan solusi pengelolaan promosi produk secara online yang dapat menjangkau wilayah yang lebih luas dan memudahkan proses transaksi. Paket kedua yang ditawarkan adalah manajemen pengelolaan pemesanan dan penjualan produk secara online

\section{METODE}

Metode pelaksanaan kegiatan terdiri dari penyusunan materi, pelatihan, pendampingan dan monitoring. Pendekatan yang dilakukan untuk proses penyusunan materi dan pelatihan adalah pendekatan konsep-proses. Pendekatan konsep proses menekankan kepada konsep e-market place dan manajemen pengelolaan pemesanan dan penjualan produk setelah itu mitra diajak untuk mengetahui cara kerja e-market place dan manajemen pengelolaan pemesanan dan penjualan produk melalui proses pelatihan. Pendekatan yang digunakan untuk proses pendampingan adalah pendekatan Project Based. Mitra dan tim pengabdian terjun bersama-sama untuk membangun e-market place, melakukan update data, publikasi website dan melakukan perbaikan manajemen pengelolaan pemesanan dan penjualan produk secara online. Pendekatan yang digunakan untuk kegiatan monitoring adalah problem solving. Tim pengabdian akan 
terus melakukan pendampingan, pemantauan dan evaluasi untuk membantu mitra mengatasi kendala yang terjadi pada proses implementasi program dan pemeliharaannya.

Tabel 1 Metode Pelaksanaan dan Pendekatan

\begin{tabular}{|c|c|c|c|}
\hline No & Solusi & $\begin{array}{c}\text { Metode } \\
\text { Pelaksanaan }\end{array}$ & Pendekatan \\
\hline a. & $\begin{array}{l}\text { Pelatihan dan pendampinngan teknik } \\
\text { promosi dan pemasaran secara online yang } \\
\text { menggunakan alat bantu e-market place }\end{array}$ & $\begin{array}{l}\text { Pelatihan dan } \\
\text { Pendampingan }\end{array}$ & $\begin{array}{l}\text { Pendekatan Konsep- } \\
\text { Proses }\end{array}$ \\
\hline b. & $\begin{array}{l}\text { Pelatihan dan pendampingan pemasaran } \\
\text { terintegrasi dan multiperangkat (website, } \\
\text { media sosial, video profil dan perangkat }\end{array}$ & $\begin{array}{l}\text { Pelatihan dan } \\
\text { Pendampingan }\end{array}$ & $\begin{array}{l}\text { Pendekatan Konsep- } \\
\text { Proses }\end{array}$ \\
\hline c. & $\begin{array}{l}\text { Sistem promosi dan pemasaran secara digital } \\
\text { yang dapat memperluas wilayah pasar dan } \\
\text { memudahkan konsumen dalam bertransaksi }\end{array}$ & $\begin{array}{l}\text { Pendampingan dan } \\
\text { monitoring }\end{array}$ & $\begin{array}{lr}\text { Pendekatan } & \text { Project } \\
\text { based dan } & \text { problem } \\
\text { solving } & \\
\end{array}$ \\
\hline d. & $\begin{array}{lcc}\text { Implementasi e-Market } & \text { Place } & \text { dan } \\
\text { Manajemen Penjualan } & & \end{array}$ & Pendampingan & $\begin{array}{lr}\text { Pendekatan } & \text { Project } \\
\text { based dan problem } \\
\text { solving }\end{array}$ \\
\hline e. & $\begin{array}{l}\text { Pelatihan dan pendampingan untuk mitra } \\
\text { terkait penyusunan Manajemen Pengelolaan } \\
\text { Pemesanan dan }\end{array}$ & $\begin{array}{l}\text { Pelatihan dan } \\
\text { Pendampingan }\end{array}$ & $\begin{array}{l}\text { Pendekatan Konsep- } \\
\text { Proses }\end{array}$ \\
\hline
\end{tabular}

\section{HASIL DAN PEMBAHASAN}

Mitra berperan aktif dalam kegiatan masyarakat dengan mengikuti pelatihan UKM online. Pelatihan meliputi mendesain e-market place, membuat e-market place, video iklan, pendaftaran domain dan hosting, pengunggahan konten toko, update data konten e-market place dan optimalisasi kegiatan promosi dan pemasaran melalui berbagai media seperti facebook, dan pembuatan profil secara online. Mitra juga mengikuti untuk manajemen pengelolaan pemesanan dan penjualan produk dengan cara yang benar dan sederhana. Setelah melalui tahap pelatihan mitra akan menjadi pusat pelaksanaan implementasi program. Mitra membangun e-market place dan pernbaikan manajemen pengelolaan pemesanan dan penjualan produk dengan pendampingan dari tim pengabdian. Proses publikasi konten website dan manajemen penegelolaan pemesanan dan penjualan secara online juga dilakukan mitra bersama tim pengabdian.

Modul pelatihan dibutuhkan agar pelatihan dapat berjalan lancar dan efisien. Modul pelatihan terdiri dari modul Instalasi, Konfigurasi e-market place dan Modul Manajemen Pengelolaan Pemesanan dan Penjualan Produk.

Untuk mengembangkan sistem promosi dan pemasaran serta manajemen usaha serta meningkatkan ketrampilan para produsen blangkon maka akan dilakukan pelatihan antara lain :

1) Pelatihan pengembangan promosi dan pemasaran secara online

Pelatihan pengembangan teknik promosi dan pemasaran secara online dilakukan dengan mengembangkan e-market place. Materi pelatihan mengacu pada modul yang telah disusun sebelumnya. Pelatihan akan dilakukan selama dua hari dengan panjang sesi pelatihan adalah empat jam. 


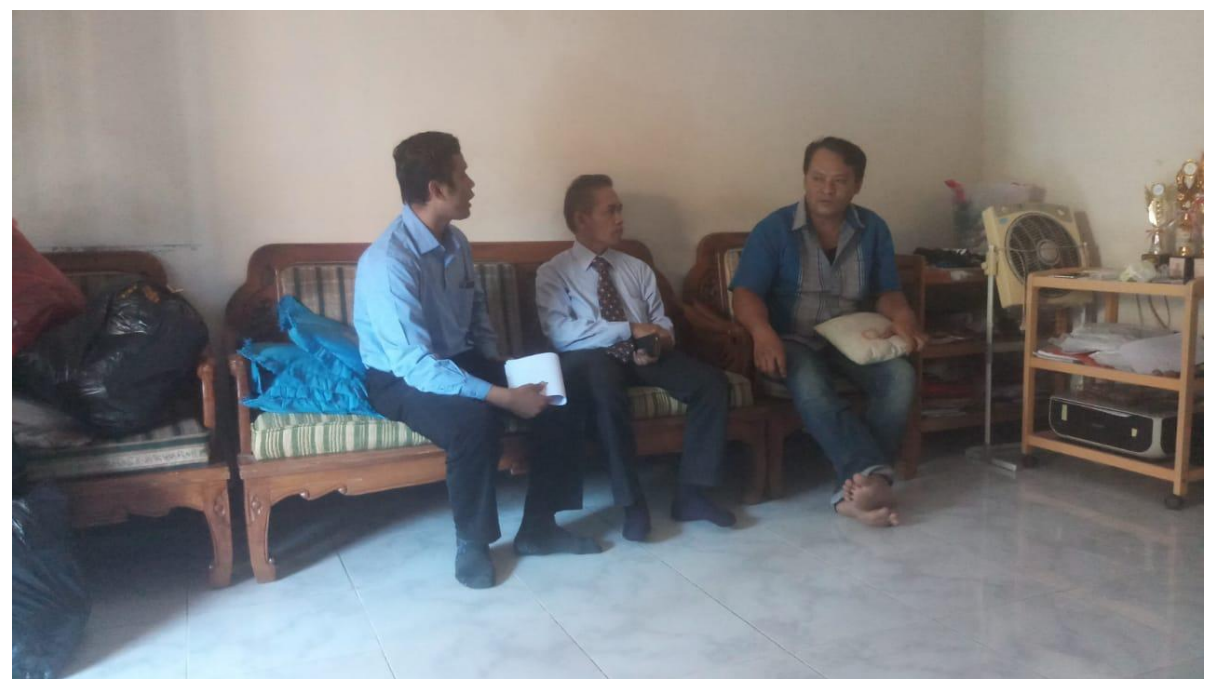

Gambar 2 Pelatihan Pemasaran

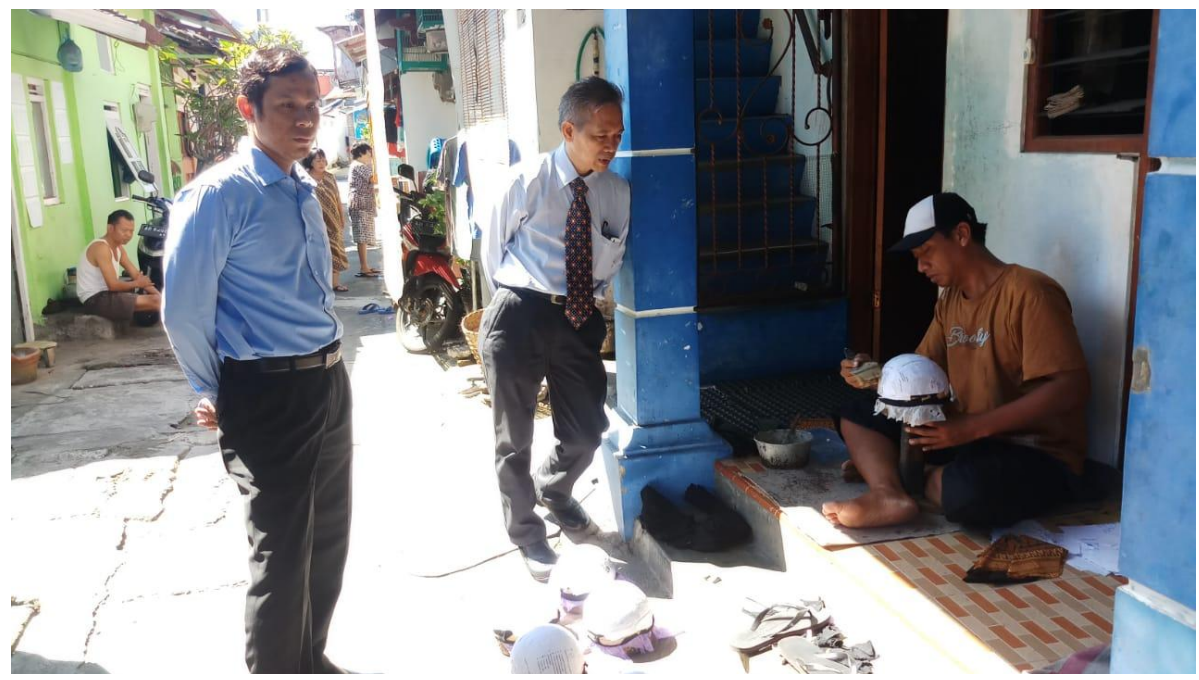

Gambar 3 Pelatihan Pemasaran

2) Pelatihan Manajemen Pengelolaan Pemesanan dan Penjualan Produk

Pelatihan manajemen pengelolaan pemesanan dan penjualan mengacu pada modul yang telah disusun sebelumnya. Pelatihan akan dilakukan selama dua hari dengan panjang sesi pelatihan adalah empat jam Setelah melalui proses pelatihan maka tim pengusul bersama dengan mitra melakukan kegiatan persiapan peralatan dan konfigurasi sistem. Persiapan peralatan menyangkut perangkat keras (komputer, modem koneksi internet), perangkat lunak (xampp, browser, e-market place). Konfigurasi sistem adalah proses instalasi dan setting aplikasi untuk persiapan implementasi program. Langkah selanjutnya adalah implementasi program adalah input data ke e-market place dan perbaiakan pengelolaan pemesanan dan penjualan produk

\section{KESIMPULAN}

Kesimpulan yang diperoleh dari kegiatan PkM Induksi Teknologi pada Industri Kreatif Kampung Sentra Blangkon : Promosi, Pengelolaan Pemesanan dan Penjualan, meliputi (1) Pelatihan pengembangan promosi dan pemasaran secara online, (2) Pelatihan Manajemen Pengelolaan Pemesanan dan Penjualan Produk dan (3) selanjutnya dapat dilakukan Persiapan Peralatan, Konfigurasi Sistem dan Implementasi Program. 


\section{SARAN}

Kegiatan pengabdian ini telah dilaksanakan dengan melatih mitra mengenai promosi, pengelolaan pemesanan dan penjualan. Dalam kegiatan ini ditemukan bahwa mitra terdapat permasalahan mengenai pengelolaan keuangan, untuk itu dapat dilakukan penelitian selanjutnya mengenai teknik pengelolaan keuangan yang tepat yang dapat dilakukan pada mitra yaitu Paguyuban Maju Utomo pada Industri Kreatif Kampung Blangkon.

\section{UCAPAN TERIMA KASIH}

Terima kasih kepada Direktorat Riset Pengabdian Masyarakat Kementerian Riset, Teknologi dan Pendidikan Tinggi yang telah memberikan pendanaan kegiatan Program Kemitraan Masyarakat ini pada tahun 2019. Ucapan terima kasih juga disampaikan kepada seluruh civitas Universitas Duta Bangsa yang telah mendukung terlaksananya Program Kemitraan Masyarakat ini. Tidak lupa, terima kasih kepada Ketua Paguyuban Maju Utomo dan seluruh anggota Paguyuban Maju Utomo atas kerjasamanya.

\section{DAFTAR PUSTAKA}

[1] Endang, M, Orland, J.I. 2013, Analisis Keputusan Pembelian Konsumen Melalui Media Online (E-Marketing), Universitas Esa Unggul Jakarta, Jurnal Ekonomi, Vol. 4, No. 2.

[2] Silalahi, M. L., 2015, Pengembangan Strategi Marketing Mix pada Seni Pertunjukan Pragina Gong dalam Industri Kreatif Indonesia, Tesis, ISI Yogyakarta.

[3] Putra, D. P., Alhamdani, M., \& Gunawan, I, 2013, Pusat Industri Kreatif di Kota Pontianak, Jurnal Online Mahasiswa Arsitektur "Langkau Betang", Vol 1, No 1, 1-2.

[4] Lukmandono, Tontowi, A. E., Sudiarso, A., \& Utomo, H., 2015, Penentuan Kriteria Daya Saing Industri Kreatif dengan Analytical Hierarchy Process, Seminar Nasional IENACO 2015, (hal. 455-462).

[5] Rudy, A, Theresia, L, Santi, W. E-Market Place Sebagai Sarana Transaksi Lelang Online, Teknik Informatika, Fakultas Teknologi Informasi, Universitas Kristen Petra.

[6] Muhammad, I. N, Muhammad, A. P, Satria, M. A. N, 2017, Pembinaan Manajemen Usaha Pada Pelaku Usaha Mikro Pengrajin Sepatu di Kecamatan Medan Denai, Fakultas Ekonomi dan Bisnis, Universitas Muhammadiyah Sumatera Utara : Prosiding SNaPp2017 Sosial, Ekonomi dan Humaniora pISSN 2089-3590|eISSN 2303-2472. 